\title{
Sigortalı Kadınların Doğum Sonrası İşe Dönüş Süreleri İçin Sağkalım Analizi Uygulaması
}

\author{
A Survival Analysis Application for Durations \\ Until Return to Work of Insured Women
}

\section{İlker ŞííiN * Tuğçe GÜZEL **}

$\ddot{O}_{z}:$ Bu çalışmanın amacı sigortalı kadınların doğum sonrasında ilk işten ayrılış zamanları ile işe dönüş sürelerinin yaş ve çocuk sayısına göre nasıl farklılaştığının araştırılmasıdır. Çalışan kadınların işe dönüş hızlarının tespitinde Sosyal Güvenlik Kurumunun 2014-2017 yılları arasındaki aylık kayıtlı sigortalı verileri baz alınmıştır. Olay tarihçesi analizi çerçevesinde sağkalım zamanları Kaplan-Meier yöntemiyle belirlenerek doğumda anne yaşı ve halihazırdaki çocuk sayısına göre sağkalım eğrileri elde edilmiştir. Araştırma, 2014 yılı içerisinde meydana gelen doğumları takiben, her bir doğum sonrası 36 aylık sürede annelerin iş hareketlerini kapsamaktadır. Buna göre, hiç ayrılmayan annelerin süreleri de dahil edildiğinde, doğumdan sonraki 12. ayda annelerin yarısı çalışma hayatından ayrılmaktadır. Herhangi bir nedenle çalışma hayatından ayrılmış olan kadınların ortalama sigortalılıkta kalabilme süresi doğum sonras1 9. aya kadardır. Ayrıca, doğumun ilk yılında sigortalılıktan ayrılan kadınların \%50'si ayrıldıktan sonraki 10. ayda hala çalışma hayatına dönüş yapmamış vaziyettedir. Anne yaşı ve çocuk sayısına göre sigortalılıkta sağkalım süreleri istatistiksel olarak birbirinden farklıdır.

Anahtar sözcükler Sağkalım Çözümlemesi, Kaplan-Meier Yöntemi, Analık İzni, Toplam Doğurganlık Hızı

Abstract: This research has been conducted to investigate how the timing of maternity leave and durations until return to work of insured women differs depending on their age and the number of children. In determining the pace of the return of working women to their job, the Social Security Instution's monthly registered insured data between 2014 and 2017 is taken as the basis. The survival durations were determined by the Kaplan-Meier method in the context of event history analysis and survival curves were obtained according to the age of the mother at birth and the current number of children. The research includes work movements of mothers for each postpartum period of 36 months following births in 2014. From this, when the periods of mothers who have never left are included, half of mothers leave working life in the 12 months after birth. Among those who exit for any reason, the average length of stay as insured is up to 9 months after birth. In addition, 50\% of women whose insurance was cut off in their first year of birth did not return to working life within the next 10 months. The hypothesis test indicates that the survival durations of insurance based upon the age of the mother and on the number of children are statistically different.

Keywords: Survival Analysis, Kaplan-Meier' Method, Maternity Leave, Total Fertility Rate

\footnotetext{
* Doktor, Sosyal Güvenlik Uzman1, Sosyal Güvenlik Kurumu, isirin@sgk.gov.tr. https://orcid.org/0000-0003-4092-1579

** Sosyal Güvenlik Uzman Yardımcısı, Sosyal Güvenlik Kurumu, e-posta: tguzel@ sgk.gov.tr
} 
Giriş

Türkiye'nin uzun vadeli hedeflerine ulaşabilmesi, sürdürülebilir kalkınmayı sağlayabilmesi, kapsayıcı, etkin ve verimli bir sosyal güvenlik sisteminin geleceği için kadın istihdamının artırılması en önemli konulardan biridir. Güncel göstergeler, bu konuda atılması gereken adımların büyüklügünü resmetmektedir. Türkiye İstatistik Kurumu (TÜİK) verilerine göre ülkemizde 2019 yılı Kasım ayında 15-64 yaş aralığında istihdam edilen kadınların oranı \%28.3 olup, bu oran aynı yaş aralığında istihdam edilen erkeklerin oranına (\%63.3) kıyasla oldukça düşüktür (TÜIK, 2020a). Aynı zamanda ülkemizde kadınların istihdam oranı OECD ülkeleri kadın istihdamı ortalamasının da (\%61.7) altındadır (OECD, 2020).

Kadınların iş gücüne katılımını belirleyen faktörler, sosyo-ekonomik ve kültürel koşullara dayanmaktadır. Genel olarak kadınların istihdama katılımının belirleyicileri refah seviyesi, eğitim, medeni durum, çocuk sayısı, hanede bakıma muhtaç kişilerin varlığı ile çocuk yetiştirmenin firsat maliyeti olarak sayılabilir (Selim \& Üçdoğruk 2003; Adresa \& Menendez 2011; Kutlar et al. 2012; Korkmaz \& Korkut 2012; Parlak 2016). Bu faktörlerden refah ve eğitim seviyesinin yükselmesi, kadınların işgücüne katılımını arttırmada önemli bir etken iken (Korkmaz \& Korkut 2012); çocuk doğurma, sahip olunan çocuk sayısı ve buna bağlı bakım yükümlülükleri ise kadınların çalışma hayatına ara vermesine ve hatta çalışma hayatından tamamen kopmasina sebep olabilmektedir.

Ülkemizde doğum sonrası dönemde çocukların bakımına ilişkin sorumlulukların büyük bir kısmı kadınlarca üstlenilmektedir. Yaş grubu 15-64 olan her 100 kişinin, bakmakla yükümlü olduğu 0-14 yaş grubundaki çocuk sayısını ifade eden çocuk bağımlılık oranı ülkemizde \%34.5 (TÜIK, 2020b) gibi yüksek bir orandır. Beş yaş altı çocukların, yaşadıkları hanelerde bakımı, \%86 oranı ile ağırlıklı olarak annelerce üstlenilmektedir (TÜİK, 2018). Çocuk bakım konusunun önümüzdeki dönemlerde de kadınların istihdama katılımını olumsuz yönde etkileyecek bir faktör olarak varlığını sürdüreceği değerlendirilebilir.

Kadınlar çocuk bakım yükümlülükleri dolayısıyla doğum sonrasında iş yaşamı ile aile yaşamı arasında seçim yapmak durumunda kalırken, cinsiyet ayrımcılığına bağlı olarak sorumlulukların ev içinde eşit paylaşılmaması, istihdama katılım önünde engeldir (Dedeoğlu \& Şahankaya 2015; Sarıca \& Çaylı 2018). Ailede çocuk bakımına ilişkin yükümlülüklerin büyük kısmının kadınlarca yerine getirilmesi hâkim toplumsal anlayışa ve kültürel alışkanlıklara dayanmaktadır. Kadınların işgücüne katılmama kararı vermesinde özellikle küçük ve bakıma muhtaç yaştaki çocukların varlığı etkili olmaktadır (Güneş et al. 2017). Bakım mesuliyetinin kadınlara yüklendiği düşünüldüğünde, iş yaşamında devamlılık bakımından kadınlar, erkeklere nazaran dezavantajlıdır. Bu konuda, Ecevit (2015) ile Dedeoğlu ve Şahankaya (2015), aile içi bakım sorumluluklarının büyük oranda kadına yüklenmesinin, kadınların çalışma kararlarına yansımasını tartışırken; Aslantepe (2015), iş yaşamı ile kesişen ailevi sorumlulukların paylaşılmasında, babalık izni vb. uygulamaların yasalarla düzenlenerek yaygınlaşması gereğine vurgu yapmaktadir.

Kadınlar, çalışma yaşamları boyunca doğum sebebiyle iş yaşamına bir ya da daha fazla kez ara verebilmektedir. Doğum sebebiyle iş yaşamına ara veren kadınlar, doğum sonrasında çocuk bakım yükümlülükleri dolayısıyla iş yaşamına aylarca veya hiç dönememektedir. Kadınlarca çocuklara harcanan zaman, işgücüne katılım ve devamlılık sağlamada önemli bir parametredir (Selim 2006). Özetle kadınların çocuk bakımına harcadığı zaman arttıkça, işgücünden ayrı kaldıkları süre de uzamaktadır.

Kadınların doğum sonrası iş ve aile yaşamı arasında tercih yapmak durumunda kalmaları, çalışma yaşamında yer almalarını etkilemenin yanı sıra çocuk yapma kararları üzerinde de etkilidir. Eğitimde geçen sürelerin uzaması nedeniyle, çalışma hayatına katılım yaş ortalaması 
artmakta ve ilk evlenme zamanı ertelenmekte, böylece doğumların ileri yaşa ötelenmesi söz konusu olmaktadır. İlk anneliğin ötelenmesi durumunda, doğurganlık süresi içerisinde çiftlerin çocuk sahibi olmaya dair tercihi, toplam sahip olacakları çocuk sayısını ve toplam doğurganlık hızını da önemli ölçüde belirlemektedir. 2001 yılında 26.7 olan ortalama doğum yaşı yıllar geçtikçe kademeli olarak artarak 2018 yılı için 28.9 olarak gerçekleşmiştir. Öte yandan, yaşa özel doğurganlık hızının en yüksek olduğu aralık 25-29 yaş aralığıdır (TÜíK 2020c). 1978 yılından bu yana, yaşa özel doğurganlığın en yüksek olduğu 20-24 yaş grubunda sürekli azalma meydana gelerek azami seviyenin 25-29 yaş grubuna çekildiği gözlenmektedir (TÜİK 2020b; Hacettepe Üniversitesi 2014, 64). Dolayısıyla ülkemizde toplam doğurganlık hızının, Birleşmiş Milletler tarafindan hazırlanan projeksiyona göre (United Nations 2017), 2025 yılında 1.88; 2050 y1lında ise 1.75 değerine düşeceğinin öngörüldüğg̈ düşünüldüğünde; toplam doğurganlığın nüfus yenileme hızının altında kalması sonucu nüfusun yaşlanması söz konusu olacaktır. Nitekim, Ailenin ve Dinamik Nüfus Yapısının Korunması Programı çerçevesinde 10. Kalkınma Planı döneminde uygulanan Dinamik Nüfus Yapısının Korunması bileşeni ile, toplam doğurganlık hızını yenileme oranı seviyesinde tutabilmek adına, aile ve iş hayatının uyumunu güçlendirici izin ve yarı zamanlı çalışma programları uygulamaya konmuştur.

Sosyal güvenlik sisteminin bir parçası olarak çalışan annelere yönelik yardımların doğurganlığı arttırıcı etkisi sıklıkla tartışılmaktadır. Böyle bir ortamda, hizmet akdiyle çalışan annelerin doğum sonrası işe dönüş zamanlarının ne tür değişiklikler gösterdiğinin bilinmesi politika tasarımında önemli bir katkı sunma potansiyeline sahiptir. Hem doğurganlığın artırılması hem de kadınların istihdam sürecinde daha fazla ve kesintisiz olarak yer almalarının sağlanması, izlenecek politika bileşimlerinde gözetilmesi gereken hassas bir dengedir.

$\mathrm{Bu}$ çalışma, kadınların doğum ve çocuk bakım yükümlülükleri nedeniyle iş yaşamından ne derece ayrı kaldıklarını verilere dayalı olarak ortaya koyması bakımından önemli olup, sonuçların kadınların doğum dolayısıyla sigortalılık süresi bakımından kaybettikleri zamanın telafisini sağlamada oluşturulacak politikaların belirlenmesinde fayda sağlayabileceği düşünülmektedir.

Çalışmada, sigortalı çalışan kadınlar arasında sayıca çoğunluğu oluşturmaları ve iş ilişkisi bakımından iş ilişkisinde karşı tarafa bağlılık özelliği göstermeleri nedeniyle hizmet akdiyle bir veya birden fazla işverene bağlı olarak çalışan sigortalı kadınlar konu edilmiştir. Bu statüde çalışan kadınların, yaş aralığı ve sahip oldukları çocuk sayısı değişkenlerine bağlı olarak doğum sonrası işe dönüş davranışları ve eğilimleri ele alınmıştır. Doğumdan sonra sigortalılıktan ilk ayrılış ile bir ayrılış yapıldıktan sonra sigortalılığa yeniden dönüş olayları Kaplan-Meier yöntemiyle ve seçilmiş değişkenlere göre zaman tarihçesi çözümlemesine tabi tutulmuştur. Yöntemin detayına ikinci bölümde yer verilmektedir.

Araştırma kapsamında aşağıdaki sorulara yanıt aranmıştır.

1. Sigortalı olarak çalışmaktayken doğum yapan kadınların ortalama kaç ay daha sigortalı statüleri devam etmektedir?

2. Sigortalı olarak çalışmaktayken doğum yapan kadınlar ortalama kaçıncı ayda işe geri dönmektedir?

3. İșten ayrılış/işe dönüş sürelerinde yaş gruplarına göre farklılaşma var mıdır?

4. İşten ayrılış/işe dönüş sürelerinde mevcut çocuk sayısına göre farklılaşma var midir?

\section{Yöntem}

$\mathrm{Bu}$ çalışmada Sosyal Güvenlik Kurumu'nun (SGK) kayıtlarından elde edilen veriler kullanılmıştır. Çalışma kapsamında Kurumdan, 1/1/2014 ile 31/12/2014 arasında doğan çocukları nedeniyle analığa bağlı geçici iş göremezlik ödeneği alan kadın sigortalıların doğumdan sonra kayıtlı sigortalılığa dönüş zamanlarına ilişkin veri temin edilmiştir. Veri, anılan aralıkta doğum 
yapan 123,228 anneyi kapsamaktadır. Analize dahil edilen kadınlar, 5510 sayılı Sosyal Sigortalar ve Genel Sağlık Sigortası Kanunu'nun 4. maddesinin birinci fikrasının (a) bendine tabi olup, kamuoyunda "SSK'lı" olarak adlandırılan gruptur. Kişilerin tanınmasına olanak vermeyecek biçimde anonim hale getirilmiş veri deseni, Microsoft Excel ortamında alınmış ve detay analizler SAS Enterprise Guide programı kullanılarak tamamlanmıştır.

Kamu kurumlarında çalışanlar ile kendi nam ve hesabına sigortalı olarak çalışan kadınlar çalışma kapsamı dışındadır. Ayrıca kayıt dışılık sorunu çerçevesinde farklı veri deseni ile çalışılması gereken sigortasız çalışan kadınların durumu da ayrı bir araştırma konusu olması sebebiyle çalışmaya dahil edilmemiştir.

Sosyal bilimlerde, doğum, ölüm, evlenme, mesleki hareketlilik ve benzeri yaşamsal olayların tarihsel verisi ile yapılan çalışmalarda, sağkalım analizi sıklıkla kullanılmaktadır (Hinde 1998, 62). Olay tarihçesi analizi olarak da adlandırılan bu yöntemde, iki olay arasındaki sürenin nasıl farklılaştığı araştırılır. Gözlenen bireylerin, analiz konusu yaşamsal olayı gözlem süresi içerisinde hiç deneyimlememesi, deneyimlemekle birlikte gözlem dönemine giriş zamanlarının bireyler arasında farklı olması gibi durumlar, olay tarihçesi analizinde dikkate alınması gereken parametrelerdir (Norusis 2008, 103). Bu araştırmada konu edilen olaylar; doğumdan sonra çalışma yaşamından ilk ayrılış ve ayrılış yapılan aydan sonra kayıtlı sigortalılığa dönüştür. Diğer bir ifadeyle bu çalışma kapsamındaki sağkalım analizi, doğum sonrasında sigortalılıkta kalma zamanı ve işten ayrılma ile sonuçlanan durumlarda işten ayrılış sonrası çalışılmayan dönemin ne kadar süre ile devam ettiğini araştırmaktadır.

$\mathrm{Bu}$ çalışmada, sağkalım çözümlemesi Kaplan-Meier yöntemiyle ve koşullu sağkalım olasılıklarının hesaplanması suretiyle elde edilmiştir. Kaplan-Meier yöntemi, her bir gözlem biriminin araştırma konusu olayı yaşayıp yaşamadığı/tecrübe edip etmediği konusunda bilgi eksikliğinin olduğu durumlarda iki olay arasındaki süreyi analiz etmede kullanılan istatistiksel teknikler arasındadır. (Kaplan \& Meier 1958; Blossfeld \& Rohwer 2002). Eryurt ve Ergöçmen (2008), birinci, ikinci ve üçüncü çocuğa geçiş sürelerinin ebeveyn eğitiminin farklı kategorilerine göre değişimini Kaplan-Meier sağkalım eğrileri vasıtasıyla tartışmıştır. İşten ayrılış nedenlerine ilişkin olarak SGK verisi ile yaptıkları çoklu azalan hayat tablosu çalışmasında Ündemir vd. (2010), hayatta kalma fonksiyonlarını Kaplan-Meier yöntemiyle elde etmiştir. Karasoy ve Tilki (2013), arasında Kaplan-Meier yönteminin de bulunduğu parametrik olmayan sağkalım fonksiyonu tahminlerini ayrıntılı biçimde incelemiştir. Yazarlara göre sağkalım fonksiyonlarının aynılığı üzerine yapılacak hipotez testlerinde seçilecek yazılımla birlikte skor testi ve ağırlıklı testlerin de önemi kayda değerdir.

Kaplan-Meier uygulamasında, $T$, sağkalım zamanını ve $P$ olasılık fonksiyonunu göstermek üzere; birikimli sağkalım fonksiyonu $S(t)$,

\section{$S(t)=P\left(t^{\prime}\right.$ den daha uzun süre hayatta kalma $)$}

$S(t)=P(T>t)$ ile gösterilmektedir. $S(t), 0 \leq S(t) \leq 1$ özelliğini sağlar. Herhangi bir $t$ anı için tahmin edilen sağkalım fonksiyonu, ilgili $t$ anından daha uzun süre sağ kalan gözlem sayısının toplam gözlem sayısına bölünmesi suretiyle hesaplanmaktadır.

Să̆ kalım süresinin belirlenemediği vakalar ise sansürlü gözlemler olarak adlandırılmaktadır. İncelenen dönemin öncesine ve sonrasına ilişkin olarak sağdan veya soldan sansürlü gözlemler söz konusu olabilmektedir. Bu makalede konu edilen olay açısından, doğumdan önceki herhangi bir ayda sigortalılıktan ayrılan ve 36 ay boyunca hiç işe giriş yapmayan anneler soldan sansürlü; doğumdan sonraki 36 ay boyunca hiç sistemden ayrılmamış olan anneler ise sağdan sansürlü gözlem olarak değerlendirilmektedir. 


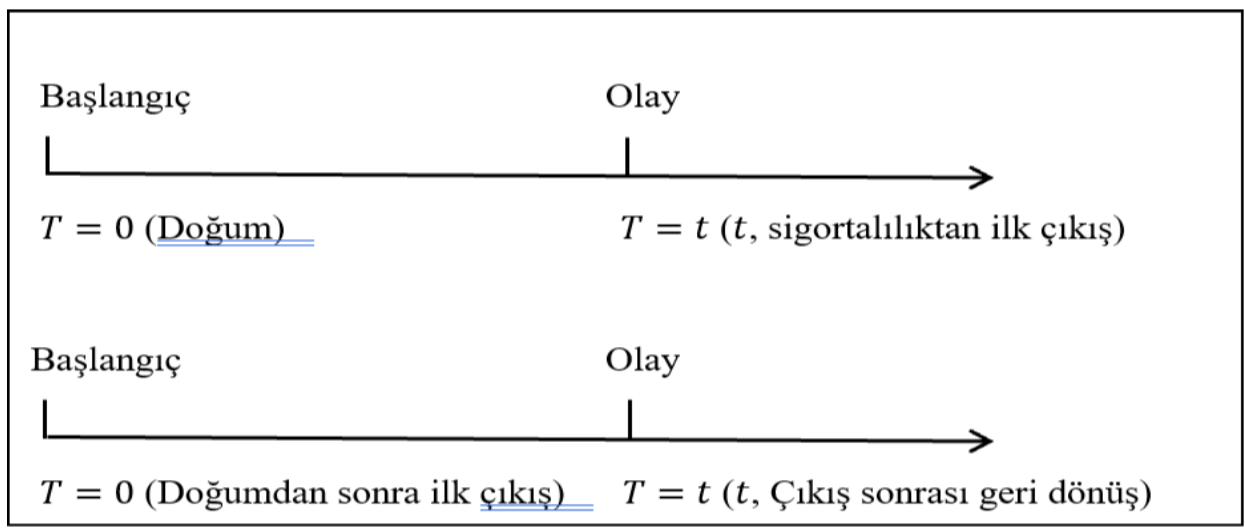

Fig. 1. Sağkalım analizinde dikkate alınan olaylar

Analiz kapsamındaki olaylar çerçevesinde sağkalım çözümlemesinin görselleştirilmiş hali Fig. 1'de betimlenmiştir. Doğumdan sonra kayıtlı sigortalılıktan ilk ayrılış olayı ile ayrılış yapmış olan kadınların yeniden çalışma hayatına dönüşü, sağkalım analizinde kullanılan iki olaydır. Olay süresi ise, her bir olay meydana gelinceye kadar geçen ay sayısıdır.

\section{Bulgular}

Araştırma bulgularına göre 1/1/2014 ile 31/12/2014 arasında doğum yapmış 123,228 kadından 41,256's1 (\%33), doğumu takip eden 36 aylık süre boyunca düzenli biçimde kayıtlı sigortalı olarak Sosyal Güvenlik Kurumuna bildirilmiştir. Şekil 1'de tanımlanan “(işten) ayrılış" olayı, doğumu takip eden 36 aylık dönemde gözlemlerin \%33'ü için meydana gelmemiş olup 41,256 tane gözlem sağdan sansürlüdür. Bu bölümde, sigortalılıktan ilk ayrılış ile ayrılıştan sonra geri dönüş zamanları iki ayrı sağkalım olayı olarak ele alınmıştır.

\section{Doğum sonrasında sigortalılıktan ilk ayrılış zamanı}

Fig. 2'de dikey eksende sağkalım olasılıkları, yatay eksende ise ay olarak zaman yer almaktadır. Burada sağkalım yönünden araştırılan olay, kayıtlı sigortalılıkta kalma halidir. Sonuçlara göre kadınların yarısı doğumdan sonraki 12. ayda sigortalılıktan ayrılmaktadır. Bu durum Şekil 2'de, dikey eksendeki 0.5 değerine karşılık yatay eksende 12. ayın karşılık bulmasıyla gözlemlenmektedir. İlk 5 ay sonunda, doğum yapmış kadınların \%75'i işten ayrılmaksızın kayıtlı sigortalı olarak devam etmektedir. Doğum sonrası 6. ay itibarıyla annelerin \%03'ü sigortalı olarak bildirilmeye devam etmektedir. Ortalama sigortalılıkta kalış süresi ise 18 aydır. Doğumdan sonra işten ayrılış 6 . ay ve sonrasında ivme kazanmaktadır.

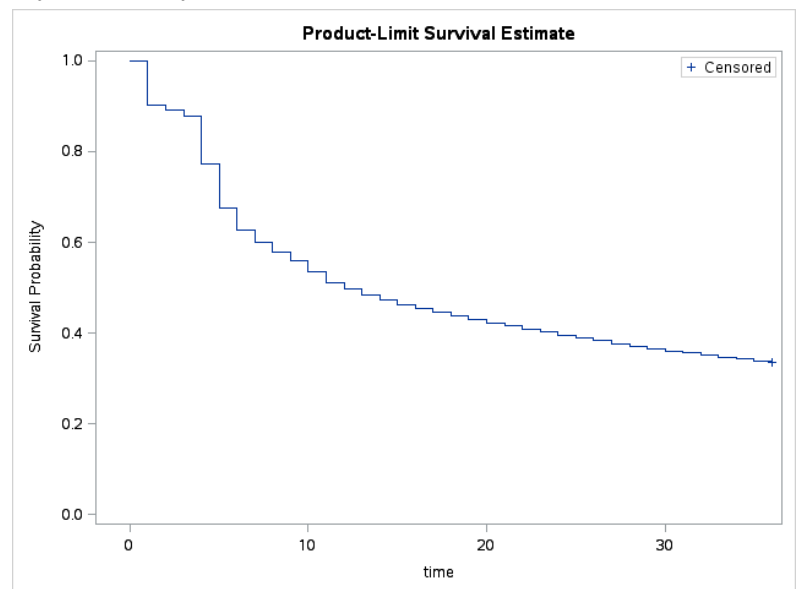

Fig. 2. Doğum sonrası sigortalılıkta kalma sağkalım eğrisi 


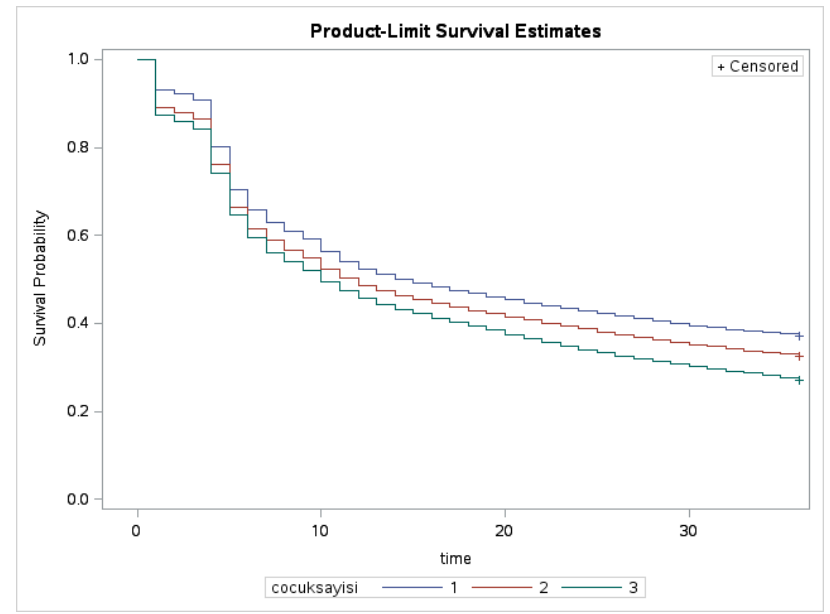

Fig. 3. Çocuk sayısına göre $(1,2,3+)$ doğum sonrası sigortalılıkta kalma sağkalım eğrileri

Kadınların çocuk sayılarına göre sağkalım süreleri Şekil 3'te gösterilmektedir. Kategorik değişken, 1 çocuklu, 2 çocuklu ile 3 ve üzeri çocuklu anneleri ifade etmektedir. Araştırmaya dahil edilen kadınların \%38'i tek, \%47'si iki, \%15'i de üç ve üzeri sayıda yaşayan çocuğa sahiptir. Eğrilerin sıralaması, çocuk sayısı azaldıkça doğum sonrası işten ayrılan kadınların oranının azaldığına işaret etmektedir. Diğer bir ifadeyle çocuk sayısı artıkça, herhangi bir ayda sigortalılığını devam ettirebilen kadınların oranı azalmakta ve işten ayrılanların oranı artmaktadır. $\mathrm{Bu}$ durum, çocuk sayısı arttıkça iş ile aile yaşamını sürdürebilme güçlüğünü işaret etmektedir. Bununla birlikte, birden fazla çocukluların işe dönüşü daha hızlıdır (Fig. 6).

Fig. 4'teki eğrilerin üstten altta diziliş sırası incelendiğinde, doğumda anne yaşı ilerledikçe doğum sonrası sigortalılıkta kalmaya devam eden kadın oranı artmaktadır (Fig. 4). Belirli bir ay için, doğum sebebiyle işten ayrılmayarak çalışmaya devam eden (sağkalan) kadınların oranı her yaş grubunda, kendinden daha alt yaş gruplarına göre daha yüksektir. İleri yaşlardaki kadınlar, gençlere nazaran doğum sonrasında iş gücünde daha uzun süre kalabilmektedir. Doğumdan sonraki ilk yılın sonunda 36 yaş ve üstü olanların \%58'i sigortalı olarak devam ederken 25 yaş ve altı grup için ilk yılın sonundaki sağkalım oranı \%38'dir.

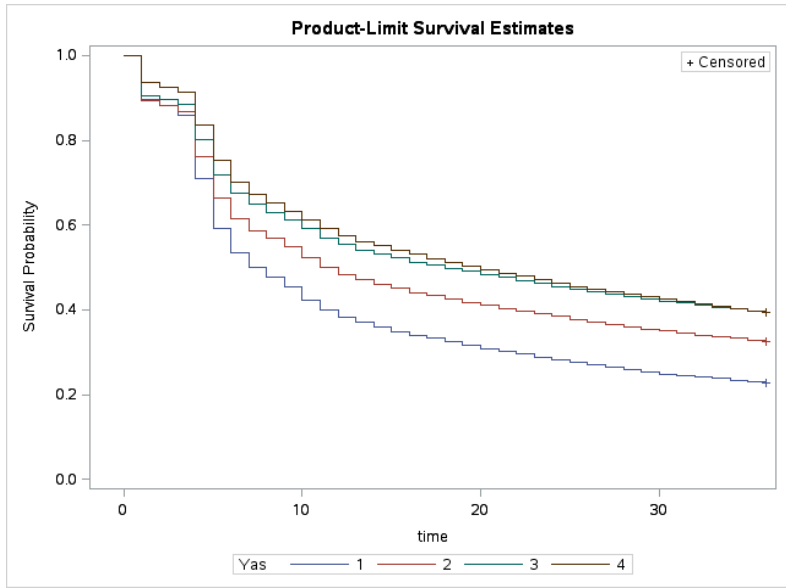

Fig. 4. Yaşa göre kadınların doğum sonrası sigortalılıkta kalma sağkalım eğrileri

Not: 1; 25 yaş ve altını, 2; 26-30 aralı̆̆ını, 3; 31-35 aralığını, 4; 36 yaş ve üstünü ifade eder

25 yaş ve altı, 26-30, 31-35 ile 36 yaş ve üstü aralıklarındaki kadınlar için medyan sağkalım süreleri sırasıyla $8,11,18$ ve 20 aydır. Bu sonuca göre, 25 yaş ve altı gruptakilerin $\% 50$ si 8 . 
ayda işten ayrılmış iken, 36 yaş ve üstü olan kadınların doğum sonrası 20. ayda hala yarısı sigortalıdır. Yaş kategorileri yukarı yönlü arttıkça, her bir ilave yaş kategorisinde bir öncekine göre doğum sonrası işten ayrılma daha geçtir.

Fig. 3 ve Fig. 4'te ifade edilen, sahip olunan çocuk sayısı ile yaşa göre sigortalılıkta kalma sürelerinin analizinde eğriler arasında istatistiksel olarak farklıdır $(\mathrm{p}=0.0001<0.01)$. Buna göre yaş ve çocuk sayısı açısından kadınların sigortalılıktan ilk ayrılış zamanları, istatistiksel olarak anlamlı ölçüde farklılaşmaktadır.

\section{Doğum ertesinde sigortalılıktan ilk ayrılış sonrası dönüş zamanı}

$\mathrm{Bu}$ makalede sağkalım çalışmasına dahil edilen iki olaydan diğeri, ilk işten ayrılış sonrasında tekrar işe dönüşe ilişkindir. Fig. 5, ilk ayrılış ertesinde ay bazında geçen süreye göre, doğum yapmış kadınların ne kadarının kayıtlı sigortalı olarak yeniden işe döndüğünü göstermektedir. Sonuçlara göre doğum ertesi ilk bir yıl içinde işten ayrılan kadınların yarısı, ayrılıştan sonraki 10. ay itibariyle halen çalışma hayatına dönememiş durumdadır. Ayrılış sonrası 6. ay itibarıyla annelerin \%32'si sigortalı olarak bildirildikleri bir işe girmiştir. Doğum sonrası bir yılda ayrılış yapmış olan kadınların ortalama geri dönüşs süresi ise işten ayrıldıktan sonraki 12. aydır.

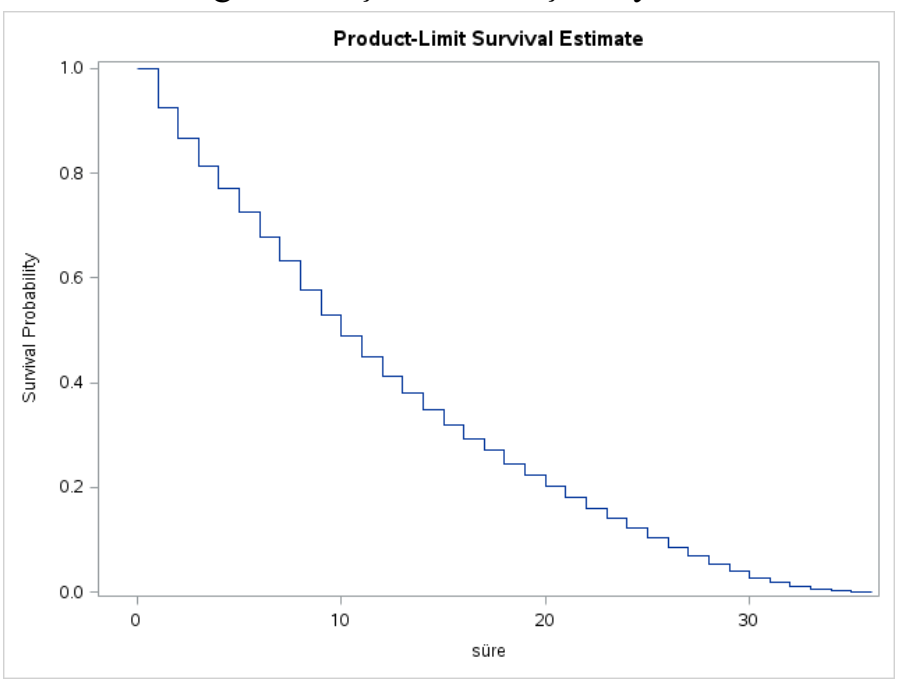

Fig. 5. Sigortalılıktan ayrılış sonrası işe dönüş sağkalım eğrisi

Kadınların çocuk sayılarına göre, ilk işten ayrılış sonrası işe geri dönüşlerine dair sağkalım eğrileri Fig. 6'da gösterilmektedir. Burada da değişken kategorileri, 1 çocuklu, 2 çocuklu ile 3 ve üzeri çocuklu anneleri betimlemektedir. Eğriler şekilde birbirlerinden farksız bir görüntü sergilese de, logrank istatistiği sonucuna göre eğrilerin aynılığına ilişkin hipotez testi reddedilmektedir. İstatistiksel olarak eğriler anlamlı biçimde birbirinden farklıdır. Medyan sağ kalım süreleri bir çocuklu kadınlar için 11 ay, 2 ile 3 ve üzeri çocuklu kadınlar için ise 10 aydır. Diğer bir ifadeyle 1 çocuklu olan annelerin yarısı 11. ay itibarıyla geri dönebilmiş iken daha yüksek çocuk sayısına sahip olan annelerin yarısının işe döndüğü ay, 10. aydır. Çocuk sayısı birden fazla olan anneler, ayrılışın ertesinde işe nispeten daha hızlı dönebilmektedir.

İki yaşamsal olay birlikte ele alındığında, birden fazla çocuğa sahip kadınlar tek çocuklulara nazaran hem doğum sonrasındaki 36 aylık süreçte işten daha erken ayrılmakta, hem de doğum sonrası süreçte daha erken işe dönmektedir (Fig. 3 ve Fig. 6). 


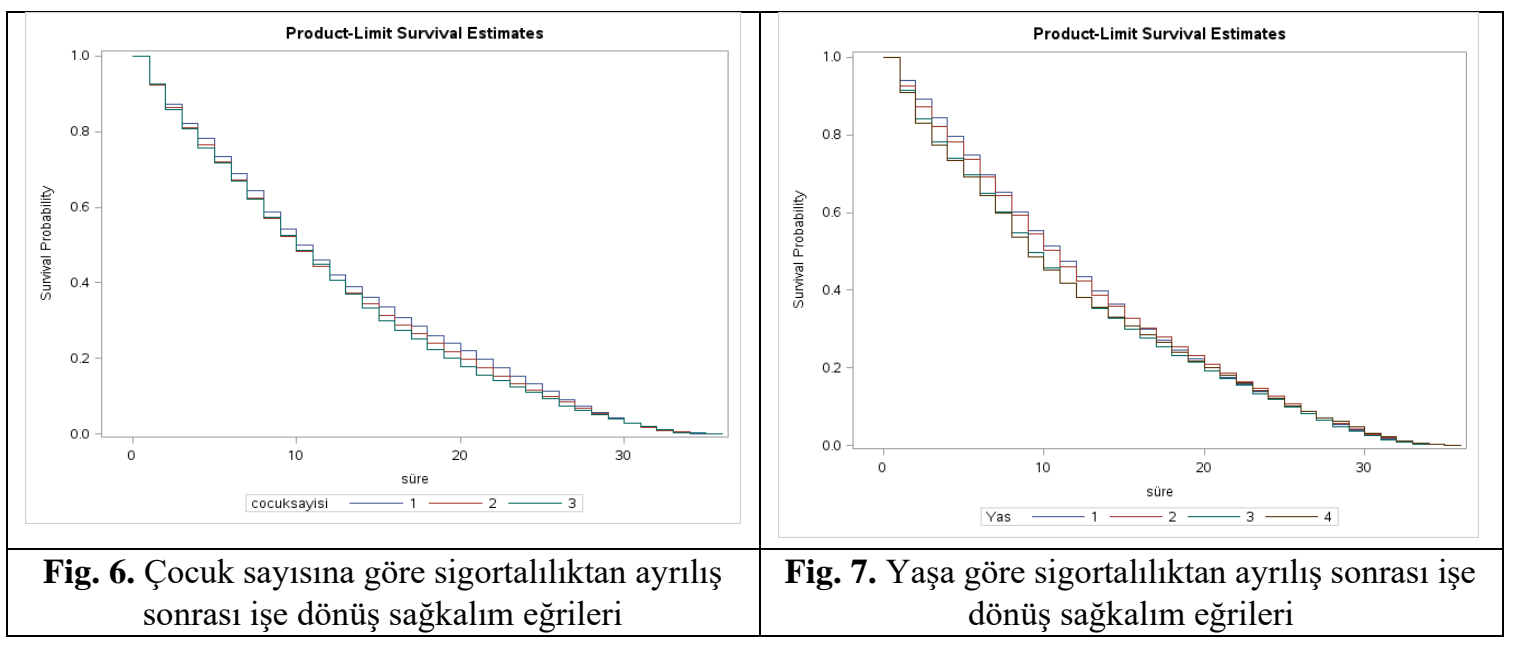

Fig. 7'de anne yaşına göre, ilk ayrılış sonrası geri dönüş̧e dair sağkalım eğrilerine yer verilmiştir. Eğriler istatistiksel olarak farklıdır $(\mathrm{p}=0.0001<0.01)$. Özellikle ilk bir yılda, yaş ilerledikçe herhangi bir aydaki işe geri dönen kadın oranı artmaktadır. İlerleyen yaşlarda kadınlar, daha genç olanlara nazaran doğum sonrasında iş yaşamına daha çabuk dönebilmektedir. 25 yaş ve altı, 26-30, 31-35 ile 36 yaş ve üstü için ayrılış hali açısından medyan sağkalım süreleri sırasıyla $11,11,9$ ve 9 aydır. 30 yaş ve altı olanların \%50'si 11. ayda geri dönmüş iken 31 yaş ve üstü olan kadınların ayrılış sonrası 9 . ayda \%50'si sigortalılığa dönmüştür.

\section{Sonuç ve Öneriler}

Bu çalışma hizmet akdiyle çalışan sigortalı kadınların doğum sonrasında ilk işten ayrılış zamanları ile işe dönüş sürelerinin yaş ve çocuk sayısına göre nasıl farklılaştığının araştırılması amacıyla yapılmıştır. Çalışan kadınların işe dönüş hızlarının tespitinde Sosyal Güvenlik Kurumunun 2014-2017 yılları arasındaki idari verileri referans alınmıştır. Çalışmada olay tarihçesi analizi çerçevesinde sağkalım zamanları Kaplan-Meier yöntemiyle belirlenerek doğumda anne yaşı ve hali hazırdaki çocuk sayısına göre sağkalım eğrileri elde edilmiştir.

Bulgular, kadınların yarısının doğumdan sonraki 12. ayda sigortalılıktan ayrıldığını göstermektedir. Kadınların doğum sebebiyle işten ayrıldıktan sonra tekrar sigortalı olarak işe dönüş süresinin ortalama olarak 12 aydır. Bu süreler çocuk sayısına ve yaş aralıklarına göre farklılaşmaktadır. Çocuk sayısı arttıkça hem işten ayrılma, hem de ayrıldıktan sonra işe dönüş daha çabuk olmaktadır. Sonuçlara göre çocuk sayısı arttıkça iş ile aile yaşamını sürdürebilme güçleşmektedir. Çocuk sayısının artışı sigortalılığın devamlılığında olumsuz bir faktör olarak görünürken, doğum yaşının ötelenmesi kadınların çalışma hayatına katılımında ve devamlılığında olumlu bir durum olarak ortaya çıkmaktadır. Sonuçlar, bazı çalışmalarda da temas edilen (Çarıkçı \& Çelikkol 2009; Topgül 2016; Özmete \& Eker 2012) ve kadınlarca üstlenilen çocuk bakım yükümlülüklerinin iş yaşamına katılıma engel oluşturduğuna yönelik tartışmalarla, paralel bir tablo sergilemektedir. Kadının aile gelirine katkısı arttıkça ücretli bakım tercihine yönelme eğiliminin arttığı dikkate alındığında (Kakıcı et al.2007), kreş ücretine destek vermeye dayalı programların tasarlanması, başta hizmet akdiyle çalışanlar olmak üzere, kadınların işe dönüşlerini hızlandıracaktır.

Öte yandan, genç yaşta olan kadınlar doğumdan sonra sigortalılıktan daha erken ayrılış yaparken, yaş ilerledikçe doğum sonrası sigortalılıkta kalma süresi uzamaktadır. Sigortalılı̆ga 
geri dönüş ise yaş arttıkça hızlanmaktadır. Genç kadınlar sigortalılıktan erken ayrılıp geç dönerken, nispeten ileri yaştakiler geç ayrılıp, erken dönmektedir. Bu durum ileri yaşta doğum yapan annelerin, kariyerlerine verdikleri arayı kapatmada gençlere kıyasla daha hızlı davrandıkları şeklinde yorumlanabilir.

2016 yılında yapılan mevzuat değişikliği ile getirilen ve birinci doğumda 60 gün, ikinci doğumda 120 gün ve sonraki doğumlarda 180 gün olarak eşlere sunulan yarı zamanlı çalışma hakkı ve yarım çalışma ödeneğinin, halihazırda doğum sonrası işten ayrılmayı önlemede sınırlı bir fayda sunduğu anlaşılmaktadır. Bununla birlikte, anılan uygulama kapsamında yarım çalışma ödeneği alabilmek, adına işsizlik sigortası primi bildirilmek (son üç yılda en az 600 gün) şartına bağlıdır. Bu koşulun hafifletilmesi halinde, kapsam genişleyerek daha fazla kadının doğum sonrası çalıșma hayatında kalması sağlanabilir. Ayrıca, evden çalıșma, küresel korona salgını nedeniyle alınan tedbirler döneminde geniş uygulama alanı bulmuştur. Evden çalışmanın doğum yapan kadınlar için mevzuat alt yapısının kurularak salgın dışı dönemlerde de uygulanması halinde işten ayrılışların azalması muhtemeldir.

\section{KAYNAKÇA}

Adresa A. \& Menendez A. (2011). "Fertility Changes in Latin America in Periods of Economic Uncertainty". Population Studies 65/1 (2011) 37-56.

Aslantepe G. (2015). Kadın İstihdamının Arttırllması ve ILO Sözleşmeleri. Geçmişten Günümüze Türkiye'de Kadın Emeği. Editörler: Ahmet Makal ve Gülay Toksöz. Ankara 2015.

Blossfeld H.P. \& Rohwer G. (2002). Techniques for Event History Modeling: New Approaches to Causal Analysis. New Jersey $2002^{2}$.

Çarıkçı İ. H. \& Çelikkol Ö. (2009). "İş-Aile Çatışmasının Örgütsel Bağlılık ve İşten Ayrılma Niyetine Etkisi”. Süleyman Demirel Üniversitesi Sosyal Bilimler Enstitüsü Dergisi (2009) 153-170.

Dedeoğlu S. \& Şahankaya, A. (2015). "Türkiye'de İş ve Aile Yaşamını Uyumlaştırma Politikaları". Der. S. Dedeoğlu \& A. Yavuz Elveren. 2000'ler Türkiyesinde Sosyal Politika ve Toplumsal Cinsiyet. Ankara (2015) 93-122.

Ecevit Y. (2015). Türkiye'de Çocuk Bakımı ve Eğitimine İki Paradigmadan Doğru Bakmak. Geçmişten Günümüze Türkiye'de Kadın Emeği. Eds. A. Makal \& G. Toksöz. Ankara (2015) 185-222.

Elveren A. Y. (2015). "Türkiye'de Sosyal Güvenlik Sisteminin Toplumsal Cinsiyet Eşitliği Açısından Bir Değerlendirmesi”. S. Dedeoğlu \& A. Yavuz Elveren. 2000'ler Türkiyesinde Sosyal Politika ve Toplumsal Cinsiyet. Ankara (2015) 63-92.

Eryurt M. A. \& Ergöçmen B. A. (2008). "Ebeveyn Eğitiminin Doğurganlık Üzerindeki Etkisi”. Nüfusbilim Dergisi 30-31 (2008) 13-28.

Gutierrez-Domenech M. (2008). "The Impact of the Labour Market on the Timing of Marriage and Births in Spain". Journal of Population Economics 21 (2008) 83-110.

Güneș C., Birecikli Ş. Ü. \& Yıldırım Z. (2017). "Çalışan Kadının Çocuk Bakım Tercihi: Havuzlanmış Verilerle Kesikli Tercih Modellerinin Karşılaştırılması". Sosyal Güvenlik Dergisi 7/1 (2017) 123-144.

Hacettepe Üniversitesi (2014). Türkiye Nüfus ve Sağlı Araştırması 2013. HÜNEE, Ankara. http://www.hips.hacettepe.edu.tr/tnsa2013/rapor/TNSA_2013_ana_rapor.pdf. adresinden ulaşılmıştır.

Hinde A. (1998). Demographic Methods. London $1998 .$.

Kakııı H., Emeç H. \& Üçdoğruk Ş. (2007). "Türkiye'de Çalışan Kadınların Çocuk Bakım Tercihleri”. Ekonometri ve İstatistik 5 (2007) 20-40.

Kaplan E. L. \& Meier P. (1958). "Nonparametric Estimation from Incomplete Observations". Journal of the American Statistical Association 53 (1958) 457-481.

Karacan C. (2010). "Kadın İstihdamının Artırılması ve Çocuk Bakımı". ÇSGB AB Koordinasyon Dairesi Başkanlığ Bülteni Mart-Nisan-Mayıs (2010) 28-31.

Karasoy D. \& Tilki B. (2003). "Yaşam eğrilerini karşılaştırmak için kullanılan skor ve ağırlıklı testler: Sayısal örnekler". İstatistikçiler Dergisi: Ístatistik\&Aktüerya 6 (2003) 1-13.

Korkmaz A. \& Korkut G. (2012). “Türkiye'de Kadının İşgücüne Katılımının Belirleyicileri”. Süleyman 
Demirel Üniversitesi İktisadi ve İdari Bilimler Fakültesi Dergisi 17/2 (2012) 41-65.

Kutlar A., Erdem E. \& Aydın F. F. (2012). "Kadınların İşgücüne Katılması ile Doğurganlık, Boşanma ve Ücret Haddi Arasındaki İlişki: Türkiye Üzerine Bir Araştırma”. Bilgi Ekonomisi ve Yönetimi Dergisi 7/1 (2012) 149-168.

Norusis, M. J. (2008). SPSS 16.0. Advanced Statistical Procedures Companion. NJ: Prentice Hall 2008. OECD. (2020, Mart 2). Işsü̈cü Istatistikleri.

https://stats.oecd.org/Index.aspx?DatasetCode=STLABOUR adresinden ulaşılmıştır.

Parlak N.K. (2016). "İş-Yaşam Dengesi Açısından Çocuk Bakım Hizmetleri”. Akademik Bakış Dergisi 58 (2016) 159-184.

Özmete E. \& Eker I. (2012). "İş-Aile Yaşamı Çatışması ve Roller: Kamu Sektörü Örneğinde Bir Değerlendirme”. Çalışma İlişkileri Dergisi 3/2 (2012) 1-23.

Sarıca Y.P.S. \& Çaylı E. (2018). "İş-Aile Yaşamında Dengeyi Bulma Çabaları: Ülke İncelemeleri”. Sosyal Güvenlik Dergisi 8/1 (2018) 95-118.

Selim, S. \& Üçdoğruk Ş. (2003). "Sayma Veri Modelleri İle Çocuk Sayısı Belirleyicileri: Türkiye'deki Seçilmiş İller İçin Sosyoekonomik Analizler”. D.E.Ü.I.I. B.F. Dergisi 18/2 (2003) 13-31.

Selim S. (2006). “Türkiye'de Evli Kadınların İşgücüne Katılımına Göre Oluşan Doğurganlık Farklılıkları: Ayrıştırma Analizi”. Gazi Üniversitesi İ̈BF Dergisi 8/1 (2006) 139-163.

Topgül, S. (2016). "İ̧̧ ve Aile Yaşamı Dengesi (zliği) nin Kadın Çalışanlar Üzerindeki Etkileri”. Journal of Management \& Economics 23/1 (2006).

Türkiye İstatistik Кититu [TÜİK]. (2020a, Şubat 26). İşgücü İstatistikleri, Kasım 2019. http://www.tuik.gov.tr/PreHaberBultenleri.do?id=33778 adresinden ulaşılmıştır.

Türkiye Istatistik Kurumu [TÜİK]. (2020b, Mart 16). İstatistiklerle Çocuk, 2018. http://www.tuik.gov.tr/PreHaberBultenleri.do?id=30708 adresinden ulaşılmıştır.

Türkiye İstatistik Kurumu [TÜIKK]. (2020c, Mart 2). Temel Doğurganlık Göstergeleri. http://www.tuik.gov.tr/PreTablo.do?alt_id=1060 adresinden ulaşılmıştır.

Türkiye İstatistik Kurumu [TÜİK]. (2018, Mart 14). Aile Yapısı Araştırması, 2016. http://tuik.gov.tr/PreHaberBultenleri.do?id=21869 adresinden ulaşılmıştır.

United Nations (2017). "World Population Prospects: The 2017 Revision. Population Database". https://population.un.org/wpp/DataQuery/

Ündemir Y. G., Özuysal, H. \& Hoşgör, Ş. (2010). "Sosyal güvenliğe kayıtlı 4/1-a bendi kapsamındaki zorunlu sigortalılara ilişkin çoklu azalan hayat tabloları”. Nüfusbilim Dergisi 32-33 (2010) 83-102. 